\title{
Business Social Responsibility to Improve New Product Development
}

\author{
Yen-Ju Wang and Li-Ren Yang
}

\begin{abstract}
Corporate social responsibility may be one of the major causes of new product development (NPD) project failure. However, many organizations ignore corporate social responsibility leading to a poor NPD performance. The primary purpose of this research was to investigate the associations among corporate social responsibility, brand image, and NPD performance. The second objective was to evaluate the mediating effect of brand image on the relationship between corporate social responsibility and NPD performance. The third objective was to determine whether the impact of brand image on NPD performance was moderated by product characteristics. The results suggest that corporate social responsibility may contribute to brand image. In addition, brand image has a significant effect on NPD performance. The testing also supports a role for brand image as a full mediator in the relationship between corporate social responsibility practices and NPD performance. The findings also indicate that project purpose has a moderating effect on the relationship between corporate social responsibility practices and NPD performance.
\end{abstract}

Index Terms-Business social responsibility, brand image, new product development, project.

\section{INTRODUCTION}

Corporate social responsibility is an important part of business strategy. It is crucial to the success of an organization. In recent years, there has been a growing trend towards increased business social responsibility effort on NPD projects. However, the literature in NPD has ignored the empirical relationship among corporate social responsibility, brand image, and NPD performance.

Some companies adopt corporate social responsibility practices in the attempt to improve a company's image. These firms also examine the practices for ways to increase competitive advantage. However, since the importance of corporate social responsibility practices can be rather intangible, this has slowed the adoption of corporate social responsibility practice. Accordingly, the importance of corporate social responsibility has been one of the major issues for both industry and academic fields. Many studies also indicated that one of the major challenges in NPD development is brand image. In order to understand the issue, there is a need for quantification of the associations among corporate social responsibility, brand image, and NPD performance. Research on the relationships should offer guides to new product development process.

While corporate social responsibility is widely accepted in

Manuscript received November 8, 2013; revised January 7, 2013.

The authors are with the Department of Business Administration, Tamkang University, Tamsui Dist., New Taipei City 251, Taiwan (e-mail: 601610222@s01.tku.edu.tw, iry@ mail.tku.edu.tw). product development, empirical evidence that supports the importance of corporate social responsibility practice in new product development is lacking. This study attempts to fill the gap in the literature by identifying the roles of brand image in the relationship between corporate social responsibility practice and new product development success. This research employed questionnaire survey for data collection. In order to explore the benefits of corporate social responsibility effort, an industry-wide survey was used to investigate NPD projects in the Taiwanese high-tech industry.

\section{Literature REVIEW AND RESEARCH HyPotheSES}

Corporate social responsibility is an important component of new product development. The literature stated that the problems related with corporate social responsibility are one of the main reasons for company failures [1]. Previous study suggested that most of the corporate social responsibility practices were difficult to identify and some were not clear and well organized [2]. It is evident that the earlier corporate social responsibility practices are adopted, company performance are improved. Thus, corporate social responsibility practice is often cited as one of the most important factor influencing company performance. A review of the literature suggested that corporate social responsibility effort may improve the performance of a company [3]-[5]. This study extends previous studies by addressing the associations between corporate social responsibility practice and new product development performance. Integrating these arguments, the following hypotheses were postulated and tested:

- H1: Corporate social responsibility practices have a significant effect on new product development performance.

On the other hand, the earlier studies supported the notion that corporate social responsibility practices may contribute to image for a product [6]-[8]. As such, corporate social responsibility practices may be positively related to product image. A review of the literature suggested that corporate social responsibility practices effort may improve product image, which subsequently affecting the performance for a new product development project [6]-[10]. Based on the relevant literature, the following hypotheses were proposed:

- H2: Corporate social responsibility practices have a significant effect on product image.

- H3: Brand image has a significant effect on new product development performance.

Above previous studies indicated that brand image may play an important role in the performance of a NPD project. In other words, NPD projects can be made more successful 
with high levels of brand image. Additionally, prior research has stated that product characteristics may play a moderating role in the relationship between brand image and NPD performance [11], [12]. Based on the previous research, the following research hypothesis was developed:

- H4: Product characteristics may act as a moderator between brand image and NPD performance.

\section{Methodology}

\section{A. Survey Process}

A survey instrument was used to measure corporate social responsibility practices, product image, and new product development performance in the Taiwanese high-tech industry. Study participants were first asked to identify a recent NPD project that they were familiar with for assessment. The survey was composed of four sections: 1) adoption of corporate social responsibility practices, 2) product image, 3) new product development performance, and 4) personal and project information. These subject projects were categorized according to seven data class variables: product type, product complexity, time availability, project purpose, consideration of customer needs, project environmental uncertainty, and project duration.

\section{B. Data Collection}

New product development projects in the Taiwanese high-tech industry were considered in this study. An industry-wide survey of adoption of corporate social responsibility practices and new product development performance was conducted between October and November 2013. The data collection tool was developed to collect project-based data. The targeted respondents were identified as the senior professions who were familiar with new product development projects.

All of the companies were then contacted via phone or email to identify the project manager or personnel involving in NPD projects by name and title. Project responses were collected by using online surveys and mail-in surveys of forms. A total of 38 NPD projects were investigated in this study. In addition, the projects were examined to ensure that no duplicate project information was collected.

\section{Construct Measurement}

The items used to measure corporate social responsibility practices were based on the questionnaires utilized by Abbott and Monsen (1979) [13]. On the other hand, items used to evaluate brand image were based on Park, Jaworski and MacInnis (1986) [14]. Finally, questions from Cooper and Kleinschmidt(1987); Griffin and Page(1996); Atuahene-Gima(1995) were adapted to measure NPD performance [15]-[17]. Each item was rated on a seven-point scale, where 1 represented strongly disagrees and 7 represented strongly agree. Content validity refers to the extent to which a measure represents all facets of a given concept. The content validity of the survey used in this study was tested through a literature review and interviews with new product development practitioners. The industry interviews encompassed three senior executives. The refined assessment items were included in the final survey.

\section{RESUlts}

\section{A. Factor Structure of Scales}

Factor analysis with Varimax rotation was used to decide the grouping of corporate social responsibility practices construct. Only variables with a factor loading greater than 0.5 were extracted. Only one factor was found to underlie corporate social responsibility practices. Additionally, the 14 items of product image construct are classified into three factors. The three dimensions categorized are perception, functionality and reputation. The analysis shows factor loadings ranging from 0.557 to 0.915 . Finally, the 15 items of NPD performance construct are classified into three factors The three constructs categorized are market performance, project performance, and overall benefit. All of the factor loadings range from 0.567 to 0.922 , indicating a high level of internal consistency among the NPD performance items. Cronbach's alpha values for the constructs are presented in Table I.

TABLE I: CRONBACH'S ALPHA VALUES FOR THE SURVEY ITEMS

\begin{tabular}{lll}
\hline \hline Construct & Subscale & Cronbach's alpha \\
\hline Corporate social responsibility & -- & 0.970 \\
Product image & Perception & 0.914 \\
Product image & Functionality & 0.904 \\
Product image & Reputation & 0.820 \\
NPD performance & Market performance & 0.924 \\
NPD performance & Project performance & 0.876 \\
NPD performance & Overall benefit & 0.864 \\
\hline \hline
\end{tabular}

\section{B. Regression Analysis Results}

Three regression models were developed using the three product image dimensions as independent variables and each of the three NPD performance measures as a dependent variable in each model. The results for market performance and project performance were significant. The regression results of the two models are presented in Table II. As shown in Table II, when market performance was used as the dependent variable (Model 1), one independent variable was identified to be significant: reputation. The findings indicate that product reputation is significantly related to market performance. The results (Model 2) also suggest that functionality may contribute to project performance. The multiple coefficient of determination ( $\mathrm{R}$ squared) was 0.489 . In other words, the independent variable, functionality, explained 48.9 percent of the variation in the dependent variable, project performance. Additionally, Kennedy (1998) noted that a variance-inflation factors (VIF) greater than 10 may be cause for concern. However, no evidence of strong multicollinearity was found in the two estimated models (i.e., the variance-inflation factors for the two models < 3) [18].

TABLE II: REGRESSION ANALYSIS RESULTS

\begin{tabular}{lll}
\hline \hline Independent variable & $\begin{array}{l}\text { Market performance } \\
\text { (Model 1) }\end{array}$ & $\begin{array}{l}\text { Project performance } \\
(\text { Model 2) }\end{array}$ \\
\hline Perception & 0.148 & 0.194 \\
Functionality & 0.145 & $0.426 *$ \\
Reputation & $0.535^{* *}$ & 0.232 \\
F-statistics & $12.500^{* * *}$ & $10.847 * * *$ \\
R squared & 0.524 & 0.489 \\
Variance-inflation factors & $<3$ & $<3$ \\
\hline \hline
\end{tabular}




\section{Mediator between Corporate Social Responsibility Practice and NPD Performance}

Formal mediation testing was subsequently conducted to determine whether brand image mediates the relationships between corporate social responsibility practices and NPD performance. The mediating role of brand image was examined by investigating changes in beta coefficients and $\mathrm{R}$-squared when entering brand image variable in a series of regression models. In the relationship between corporate social responsibility practices and NPD performance, the first three conditions for mediation specified by Baron and Kenny [19] were met by brand image dimension. Thus, brand image variable was subsequently tested to determine if it fulfilled the fourth condition for mediation.

The analysis assessed the effect of including brand image in hierarchical linear regressions where corporate social responsibility practices were the independent variables and NPD performance was the dependent variable. Multiple regression models were developed with corporate social responsibility practices, brand image, and NPD performance in order to measure the mediating role of brand image. While NPD performance is the dependent variable, corporate social responsibility practices was entered on the first step (Model 1) and brand image was entered on the second step (Model 2).

Table III presents summary of Hierarchical Regression Analysis. The first model (i.e. corporate social responsibility practices) explained $20.9 \%$ of the variance in NPD performance $(p<0.01)$. Model 2 (i.e. corporate social responsibility practices and brand image) explained $46.7 \%$ of the variance in NPD performance $(p<0.001)$. No evidence of strong multicollinearity was found in Model 2 (i.e., the variance-inflation factors for the model < 2). With the addition of brand image, corporate social responsibility practices was no longer significant in explaining variance in NPD performance. However, the beta coefficient for brand image is significant. This suggests that brand image fully mediated the effects of corporate social responsibility practices on NPD performance.

TABLE III: MEDIATOR BETWEEN CORPORATE SOCIAL RESPONSIBILITY AND NPD PERFORMANCE

\begin{tabular}{lll}
\hline \hline Independent variable & \multicolumn{2}{l}{ NPD performance } \\
\cline { 2 - 3 } & Model 1 & Model 2 \\
\hline Corporate social responsibility practice & $0.457 * *$ & 0.227 \\
Brand image & -- & $0.584 * * *$ \\
R-Squared & 0.209 & 0.467 \\
F-Statistic & $9.516^{* *}$ & $17.267 * * *$ \\
Variance-inflation factors & -- & $<2$ \\
\hline \hline
\end{tabular}

\section{Moderating Role of Project type}

In order to identify homogeneous projects clusters with the same levels of brand image, a K-means cluster analysis was performed on the basis of the three dimensions of brand image. The cluster analysis has identified two clusters for brand image, with the cluster mean values of discriminating variables given in Table IV. In addition, independent-samples $\mathrm{t}$ tests were undertaken to assess the internal validity of the cluster results. The independent-samples tests shown in Table IV confirm that the two variables do significantly differentiate across the two clusters. The first cluster was labelled projects with high degree of brand image. The second cluster consists of projects with low degree of brand image.

TABLE IV: DISCRIMINATING VARIABLES OF BRAND IMAGE

\begin{tabular}{lllllll}
\hline \hline Variable & \multicolumn{2}{l}{$\begin{array}{l}\text { Projects with high } \\
\text { brand image }\end{array}$} & \multicolumn{2}{l}{$\begin{array}{l}\text { Projects with low } \\
\text { brand image }\end{array}$} & \multicolumn{2}{l}{ t-statistic p-value } \\
\cline { 2 - 5 } & Number & Mean & Number & Mean & & \\
\hline Perception & 19 & 5.13 & 19 & 3.47 & 5.778 & 0.000 \\
Functionality & 19 & 5.97 & 19 & 5.12 & 2.845 & 0.008 \\
Reputation & 19 & 5.84 & 19 & 4.11 & 7.126 & 0.000 \\
\hline \hline
\end{tabular}

The projects were examined by clustering them on the basis of differences in perceptions of the proposed brand image dimensions. The study reveals two segments for the brand image dimensions. On the other hand, these subject projects were also categorized according to seven data class variables: product type, product complexity, time availability, project purpose, consideration of customer needs, project environmental uncertainty, and project duration. Thus, for example, to test for the moderating influence of project purpose on the relationship between brand image and NPD performance, 2 (brand image) $\times 2$ (project purpose) analysis of variance (ANOVA) was performed. The two-way ANOVA was utilized to determine the joint effects of brand image and project purpose on NPD performance. The results indicate a significant interaction of brand image and project purpose for NPD performances $(F=6.821, p<0.05)$. The findings suggest that project purpose has a moderating effect on the relationship between brand image and NPD performance. Fig. 1 shows the relationship between brand image and NPD performance at different project purpose. The analyses suggest that projects for improvements to existing products were more likely to be successful when they experienced a high level of brand image than projects for new product lines to the firm.

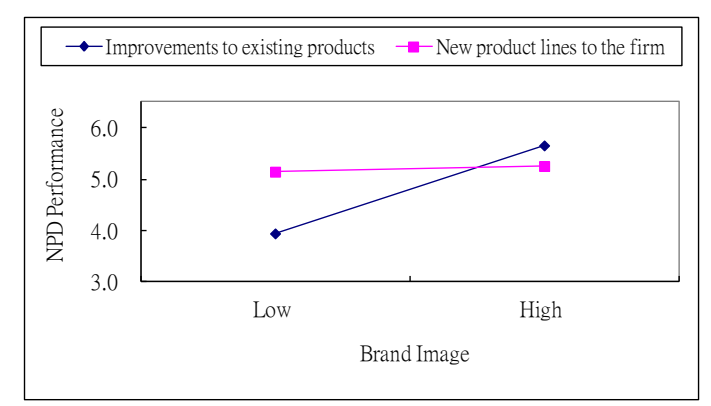

Fig. 1. Project purpose in the relationship between brand image and NPD performance

\section{CONCLUSIONS}

While the diverse benefits of adoption of corporate social responsibility practices have received substantial attention, empirical evidence that supports the importance of corporate social responsibility practices in new product development is lacking. The primary purpose of this study was to determine the relationships among corporate social responsibility, brand image, and NPD performance. The second objective was to examine the mediating effect of brand image on the relationship between corporate social responsibility practices 
and NPD performance. The third objective was to determine whether the impact of brand image on NPD performance was moderated by product characteristics.

The results suggest that adopting corporate social responsibility practices may contribute to brand image. In addition, NPD performance can be achieved with higher levels of brand image. The testing also supports a role for brand image as a full mediator in the relationship between corporate social responsibility practices and NPD performance. Finally, the findings indicate that project purpose has a moderating effect on the relationship between brand image and NPD performance. It is clear that projects for improvements to existing products were more likely to be successful when they experienced a high level of brand image than projects for new product lines to the firm.

The research results offer guides to new product development process. Findings from this study are helpful to project planners in deciding whether to adopt corporate social responsibility practices in new product development process. Project planners can use the research results to modify their current process. However, one limitation of this study is its cross-sectional design. An objective for future study is to determine how corporate social responsibility practices are changing over time. Survey with a longitudinal design may be needed to gain deeper insights into the benefits of corporate social responsibility effort.

\section{REFERENCES}

[1] D. Keith, "California management review," University of California Press, 1960.

[2] A. Williams and D. Siegel, "Corporate social responsibility: a theory of the firm perspective," Academy of Management Review, vol. 26, no. 1, pp. 117-127, 2001 .

[3] M. E. Drumwright, "Company advertising with a social dimension: the role of noneconomic criteria," Journal of Marketing, vol. 60, no. 4, pp 71-87, 1996.

[4] J. M. Handelman and S. J. Arnold, "The role of marketing actions with a social dimension: appeals to the institutional environment," Journal of Marketing, vol. 63, no. 3, pp. 33-48, 1999.

[5] B. K. de Tienne and L. W. Lewis, "The pragmatic and ethical barriers to corporate social responsibility disclosure: The Nike case," Journal of Business Ethics, vol. 60, pp. 359-376, 2005.

[6] T. B. Cornwell and I. Maignan, "An international review of sponsorship research," Journal of Advertising, vol. 27, no. 1, pp. 1-21, 1998.

[7] M. G. Crowley, "Prioritizing the sponsorship audience European," Journal of Marketing, vol. 25, no. 11, pp. 11-21, 1991.
[8] K. P. Gwinner, "A model of image creation and image transfer in event sponsorship," International Marketing Review, vol. 14, no. 3, pp. 145-158, 1997.

[9] D. L. Loudon and A. J. D. Bitta, Consumer Behavior, 3rd ed., New York, NY: McGraw-Hill Book Company, 1998.

[10] P. Kotler and W. Pfoertsch, B2B brand management [electronic resource], Springer, 2006.

[11] E. W. Larson and D. H. Gobeli, "Organizing for product development projects,” Journal of Product Innovation Management, vol. 5, no. 3, pp. 180-90, 1988.

[12] R. Müller and J. R. Turner, "Matching the project manager's leadership style to project type," International Journal of Project Management, vol. 25 , no. 1 , pp. 21-32, 2007.

[13] W. F. Abbott and R. J. Monsen, "On the measurement of corporate social responsibility: self-reported disclosures as a method of measuring corporate social involvement," Academy of Management Journal, vol. 22, no. 3, pp. 501-515, 1979.

[14] C. W. Park, B. J. Jaworski, and D. J. MacInnis, "Strategic brand concept-image management," Journal of Marketing, vol. 50, no. 4, pp. 135-145, 1986.

[15] A. Griffin and A. L. Page, "An interim report on measuring product development success and failure," Journal of Product Innovation Management, vol. 10, no. 4, pp. 291-308, 1993.

[16] K. A. Gima, "An exploratory analysis of the impact of market orientation on new product performance-a contingency approach," Journal of Product Innovation Management, vol. 12, no. 4, pp. 275-293, 1995.

[17] R. G. Cooper and E. J. Kleinschmidt, "What makes a new product a winner: success factor at the project level R\&D," Management, vol. 17 , pp. $175-190,1987$.

[18] A. Kennedy, "Acculturation and coping: A longitudinal study of Singaporeans studying abroad," presented at the Annual Conference of the Society of Australasian Social Psychologists. Christchurch, New Zealand, 1998.

[19] R. M. Baron and D. A. Kenny, "The moderator-mediator variable distinction in social psychological research: conceptual, strategic, and statistical considerations," Journal of Personality and Social Psychology, vol. 51, no. 6, 1986.

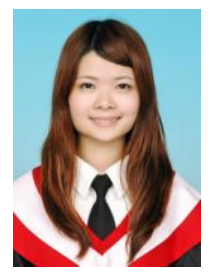

Yen-Ru Wang is a master student of Business Administration at Tamkang University. Yen-Ru Wang is the first author and can be contacted at: 601610222@s01.tku.edu.tw.

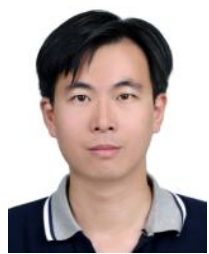

Li-Ren Yang is a professor of Business Administration at Tamkang University. He was born in Taipei City, Taiwan. He received his doctoral degree from the University of Texas at Austin. Yang's research interest is on project management, technology management, and benchmarking strategies. Li-Ren Yang is the corresponding author and can be contacted at: iry@mail.tku.edu.tw. 